\title{
高时空分辨率研究海盐液滴快速风化过程
}

\author{
全海杰 ${ }^{1}$ 钱正纲 ${ }^{1} \quad$ REID Jonathan $\mathrm{P}^{2}{ }^{2}$ 张皿宏 ${ }^{1, *}$ \\ ('北京理工大学物理化学研究所, 簇科学重点实验室, 北京 100081; \\ ${ }^{2}$ School of Chemistry, University of Bristol, Bristol, BS8 1TS, UK)
}

\begin{abstract}
摘要：以高速摄像仪与显微拉曼光谱联用研究聚四氟(疏水)乙烯基底和石英(亲水)基底上的单个海水液滴的 快速风化过程. 海水液滴风化的形貌图像达到毫秒时间分辨率和微米空间分辨率. 通入干氮气后海水液滴在石 英基底上发生快速风化过程, 首先析出 $\mathrm{Na}_{2} \mathrm{Ca}_{5}\left(\mathrm{SO}_{4}\right)_{6} \cdot 3 \mathrm{H}_{2} \mathrm{O}$ 和 $\mathrm{Na}_{2 \times} \mathrm{Ca} \mathrm{Ca}_{6-x}\left(\mathrm{SO}_{4}\right)_{6} \cdot 3 \mathrm{H}_{2} \mathrm{O}(0<x<1)$ 晶体, 然后析出 $\mathrm{NaCl}$ 晶体, 最后析出 $\mathrm{KMgCl}_{3} \cdot 6 \mathrm{H}_{2} \mathrm{O}$ 晶体. 我们发现在快速降低湿度的过程中析出钻钠复盐, 在缓慢降低湿度 的过程中析出 $\mathrm{CaSO}_{4} \cdot 2 \mathrm{H}_{2} \mathrm{O}$, 并已经确定各种结晶产物的位置以及 $\mathrm{Na}_{2} \mathrm{Ca}_{5}\left(\mathrm{SO}_{4}\right)_{6} \cdot 3 \mathrm{H}_{2} \mathrm{O}$ 和 $\mathrm{CaSO}_{4} \cdot 2 \mathrm{H}_{2} \mathrm{O}$ 两种 晶体的生长速率, 并在聚四氟乙烯基底上观察到中空结构的海盐颗粒.
\end{abstract}

关键词： 海盐; 高速摄像； 拉曼光谱； 风化；相对湿度

中图分类号: 0642

\section{High Temporal and Spatial Resolution Measurements of the Rapid Efflorescence of Sea Salt Droplets}

\author{
TONG Hai-Jie ${ }^{1} \quad$ QIAN Zheng-Gang ${ }^{1} \quad$ REID Jonathan P. ${ }^{2} \quad$ ZHANG Yun-Hong,** \\ ('Institute of Chemical Physics, Key Laboratory of Cluster Science, Beijing Institute of Technology, Beijing 100081, P. R. China; \\ ${ }^{2}$ School of Chemistry, University of Bristol, Bristol, BS8 ITS, UK)
}

\begin{abstract}
The rapid efflorescence of individual seawater droplets on polytetrafluoroethylene (PTFE, hydrophobic) and quartz (hydrophilic) substrates was investigated using a high-speed camera for imaging and micro-Raman spectroscopy to spatially resolve the particle composition. The morphology of the evaporating sea salt particles was captured using millisecond time resolution and micrometer spatial resolution. Upon rapid desiccation with dry $\mathrm{N}_{2}$ on a quartz substrate, $\mathrm{Na}_{2} \mathrm{Ca}_{5}\left(\mathrm{SO}_{4}\right)_{6} \cdot 3 \mathrm{H}_{2} \mathrm{O}$ and $\mathrm{Na}_{2 \times} \mathrm{Ca}_{6-x}\left(\mathrm{SO}_{4}\right)_{6} \cdot$ $3 \mathrm{H}_{2} \mathrm{O}(0<x<1)$ crystallized first followed by $\mathrm{NaCl}$ and finally $\mathrm{KMgCl}_{3} \cdot 6 \mathrm{H}_{2} \mathrm{O}$. We determined the formation behavior of the mixed sodium-calcium salts as crystallization products during the quick desiccation process and $\mathrm{CaSO}_{4} \cdot 2 \mathrm{H}_{2} \mathrm{O}$ during the slow desiccation process. In addition, the crystallization location of different crystal products were identified and the growth speed of $\mathrm{Na}_{2} \mathrm{Ca}_{5}\left(\mathrm{SO}_{4}\right)_{6} \cdot 3 \mathrm{H}_{2} \mathrm{O}$ crystal was compared with that of $\mathrm{CaSO}_{4} \cdot 2 \mathrm{H}_{2} \mathrm{O}$ crystal. Moreover, sea salt particles with a hollow structure were observed on the PTFE substrate at the end of the quick efflorescence process.
\end{abstract}

Key Words: Sea salt; High-speed photography; Raman spectroscopy; Efflorescence; Relative humidity

\section{Introduction}

As an important component of marine aerosol, sea salt aerosol (SSA) is produced predominantly by bubble bursting and the formation of spume droplets with the action of the wind on the ocean. ${ }^{1-3}$ SSA affects climate by the scattering and absorption of radiation, ${ }^{4}$ as well as by forming cloud condensation nu-

Received: June 2, 2011; Revised: August 31, 2011; Published on Web: September 13, 2011.

*Corresponding author. Email: yhz@bit.edu.cn; Tel: +86-10-86668406; Fax: +86-10-68913596.

The project was supported by the National Natural Science Foundation of China (20933001, 20873006).

国家自然科学基金(20933001, 20873006)资助项目

(C) Editorial office of Acta Physico-Chimica Sinica 
clei $(\mathrm{CCN})^{3-5}$ and acting as sites for heterogeneous chemical reactions. ${ }^{6,7}$ SSA can be transported inland and can undergo accumulation or efflorescence processes. ${ }^{8}$

In the past several decades, numerous studies of the evaporation of water from single SSA particles have been reported, including studies of the deliquescence and efflorescence processes. ${ }^{9-15}$ Experiments based on the scanning electron microscope (SEM) and energy-dispersive X-ray spectroscopy (EDXS) by Cheng et al. ${ }^{10,11}$ confirmed the formation of hollow sea salt particles and observed the crystallization of sulfates and sodium chloride in individual seawater droplets. In our previous work, ${ }^{16}$ the phase separation of different components within an individual seawater droplet during the evaporation process was monitored using spatially-resolved micro-Raman spectroscopy. The sequential crystallization of $\mathrm{CaSO}_{4} \cdot x \mathrm{H}_{2} \mathrm{O}(x=0.5$ or 2$), \mathrm{NaCl}$, $\mathrm{KMgCl}_{3} \cdot 6 \mathrm{H}_{2} \mathrm{O}$, and $\mathrm{MgSO}_{4}$ was observed as the relative humidity $(\mathrm{RH})$ decreased.

Despite the identification of crystal structures and compositions, the dynamics of crystallization of single SSA droplets during a rapid efflorescence process remains unclear. The solubility and crystallization kinetics of sea salt are significantly influenced by ionic strength, ${ }^{17}$ temperature,${ }^{18}$ and the presence of interfaces. ${ }^{19}$ Identifying the location of crystallization and the composition of different crystals formed during the drying of sea salt aerosol is necessary for understanding the role of SSA in the atmosphere and their micro-physical and chemical evolution. Though many previous studies have examined the crystallization process for single droplets residing on different substrates, ${ }^{16,19,20}$ the influence of the substrate on the crystallization process remains unclear and a better understanding of substrate effects must be achieved.

In this study a high-speed camera combined with microRaman spectroscopy was successfully used to monitor the dynamic changes in phase and composition of single seawater droplets during rapid efflorescence. The location and crystallization mechanisms of different sea salts were investigated. Studies were performed on both PTFE and quartz substrates.

\section{Experimental}

A schematic diagram of the experimental setup is represented in Fig.1. The micro-Raman system (Renishaw InVia, Fig.1(b)) used in this study is identical to that used in our previous work. ${ }^{16}$ A high speed CCD camera (MS55K, from Mega Speed Company of Canada, 1280 pixel $\times 1024$ pixel, maximum time-resolution of $10 \mu \mathrm{s}$, Fig.1(a)), is used to acquire images with a time-resolution of $20 \mathrm{~ms}$. This is coupled to a microscope (BMX, from Shanghai Optical Instrument Factory, maximum spatial resolution of $1 \mu \mathrm{m}$ ) to monitor the morphologic changes of the seawater droplet.

A seawater droplet was prepared by spraying natural seawater (Qingdao, China) onto either quartz or PTFE substrate (Zhejiang Yuhuan Xinde Valve Factory, with a thickness of 0.08 $\mathrm{mm}$ ) in a relative humidity controlled sample chamber (Fig.1

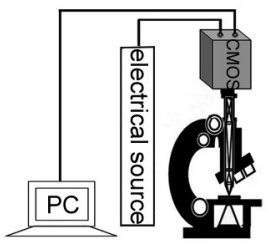

(a)

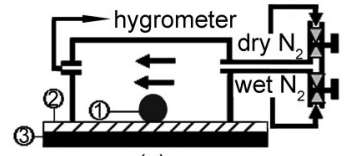

(c)

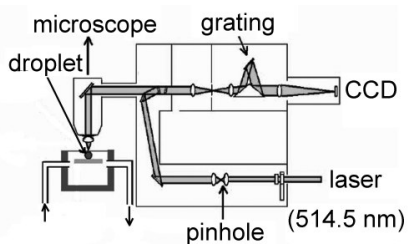

(b)
Fig.1 Schematic diagram of the experimental setup for the high-speed camera

(a) combined with micro-Raman, (b) technique measurements of single seawater droplet deposited on a PTFE or quartz substrate. (c) (1), (2) and (3) in

(c) correspond to a seawater droplet, the PTFE substrate, and the quartz substrate, respectively. The images of (d), (e) and (f) are real sea water droplet, pure water droplet with a contact angle of $150^{\circ}$ on PTFE substrate, and a crystallized $\mathrm{NaCl}$ particle on quartz substrate.

(c)). Rapid efflorescence was induced by switching from a wet $\mathrm{N}_{2}$ flow to dry $\mathrm{N}_{2}$ flow directly. All the measurements were carried out at an ambient temperature of $(22 \pm 1){ }^{\circ} \mathrm{C}$.

\section{Results and discussion}

We consider the morphological changes observed from evaporation measurements made on PTFE and quartz substrates separately before discussing the spatially resolved Raman measurements of composition on a quartz substrate.

\subsection{Morphological changes of single seawater droplet on a hydrophobic PTFE substrate}

PTFE is a hydrophobic substrate for supporting the seawater droplets: the high contact angle ( $>90^{\circ}$, Fig.1(d)) of the droplet on the surface minimizes substrate effects and allows the particle to undergo efflorescence in a manner similar to natural sea salt aerosols. Fig.1(e) is a pure water droplet with a contact angle of $150^{\circ}$ on a PTFE substrate ${ }^{21}$ for comparison.

Fig.2 illustrates the main morphological changes of an individual seawater droplet resting on the PTFE substrate during the efflorescence event. The images in Fig. 2 are selected from the continual recorded video at a rate of 50 frames per second. In the initial time range $(0-260 \mathrm{~s})$ following the introduction of a dry nitrogen gas flow, the sample on the hydrophobic surface remained as an almost spherical droplet (image 1 in Fig.2) with a smooth surface. During this time period, the droplet was observed to decrease markedly in size as water evaporated. Progressively, numerous crystals precipitated out and moved freely on the surface of the droplet. Crystals were first observed in areas $\mathrm{A}$ and $\mathrm{B}$, then in areas $\mathrm{C}, \mathrm{D}, \mathrm{E}$, and $\mathrm{F}$ in images 4 and 5 . Even though it was difficult to monitor the growth of an individual crystal because of the abrupt appearance of large number of solid particles and their irregular motion on the water surface, we were able to observe the continuous growth process of a cluster of square $\mathrm{NaCl}$ crystals, which continuously evolved from image 4 to 5 in the area of $\mathrm{E}$ in four seconds 


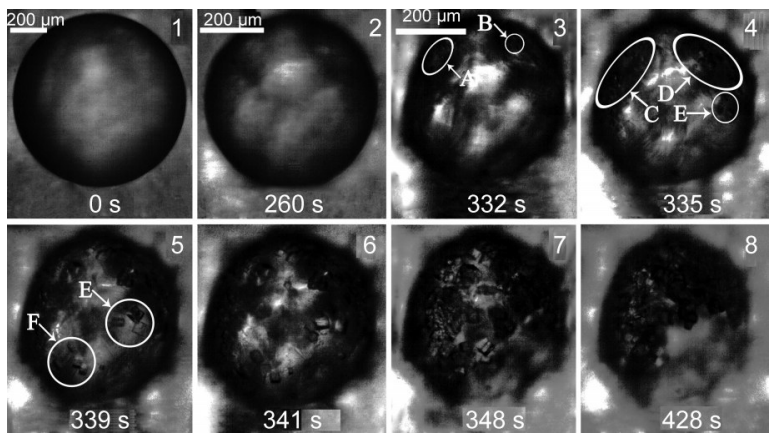

Fig.2 Images of seawater droplet on the hydrophobic PTFE substrate during the desiccation process

The same scale used in image 3 is used in images 4 to 8 .

(from 335 to $339 \mathrm{~s}$ ). At the same time, more crystals with similar square morphology were observed in image 5 (in area F). With increasing time, the solid islands of crystals were observed to accumulate to form a continental plate as the droplet continued to shrink through loss of water and decrease in sample surface area, as seen in image 6 . The sample wall was observed to collapse on complete evaporation of water, as seen in images 7 and 8. At completion, the solid sample was re-orientated and a hollow structure with an obvious opening was observed with the microscope.

It should be mentioned that there was a transition from a homogeneous aqueous droplet to an inhomogeneous solution as apparent in images 1 and 2 in Fig.2 (260 s). A large number of small crystals may be formed at the surface, induced by the inhomogeneity in composition and higher concentration of solute that exists in this region during evaporation. A timescale of 10 $\mathrm{s}$ for diffusion over a length scale equivalent to the droplet radius should be compared with the rapid retraction of the surface boundary during evaporation. The inhomogeneity in composition leads to an increased opaqueness due to increased light scattering from the droplet surface and is consistent with the previous observation of a solid shell around a $\mathrm{NaCl}$ droplet by Braun and Krieger. ${ }^{22}$

Although identifying the formation of crystals due to efflorescence is possible, a method must be found to indentify the compositions of the formed solid particles. This is essential to understand the dynamics of crystallization of sea aerosols.

\subsection{Morphological changes of single seawater droplet on a hydrophilic quartz substrate}

The image of an effloresced $\mathrm{NaCl}$ crystal on a quartz substrate is shown in Fig.1(f), leading to the formation of a single macroscopic sodium chloride crystal. By contrast, Fig.3 shows the morphological changes that occur throughout an individual seawater droplet on a hydrophilic quartz substrate during the efflorescence process. A larger number of smaller crystals are formed. The droplet on the quartz substrate has an elliptical morphology (image 1 in Fig.3) with a contact angle smaller than $90^{\circ}$ and the interference of the hydrophilic substrate should be anticipated. However, this configuration does allow the interrogation of the individual crystal structures that are

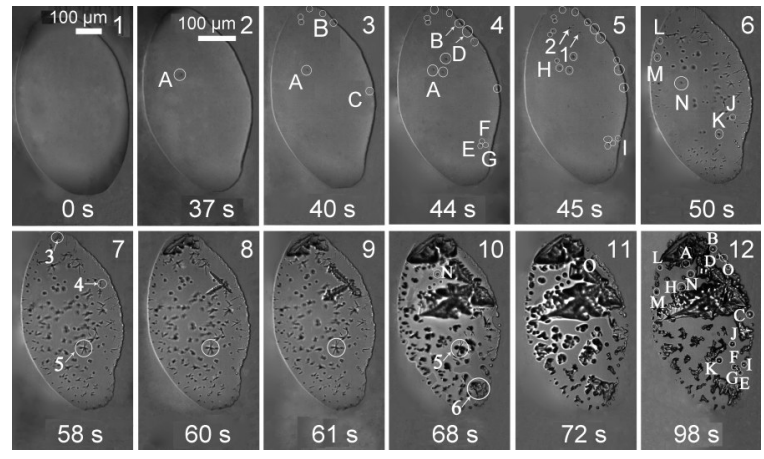

Fig.3 Images of seawater droplet on the hydrophilic quartz substrate during the desiccation process

The same scale used in image 2 is used in images 3 to 12 . There is no

relationship between the number of pictures and the numbers in pictures.

formed by micro-Raman spectroscopy, which cannot be routinely achieved for crystals of the type observed on a PTFE substrate with structures similar to those in Fig.2.

The droplet size diminished rapidly as water evaporated following the introduction of a dry nitrogen gas flow at $t=0 \mathrm{~s}$. A small crystal (in area A) precipitated out and was first observed at $37 \mathrm{~s}$ (image 2), growing bigger with further evaporation of water. Further drying led to the precipitation of more small crystals similar to B and C (image 3). Crystals of D, E, F, and G were observed in image 4 (44 s), with crystals of $E$ and $G$ having similar morphology to A. After a further $1 \mathrm{~s}$, crystals $\mathrm{H}$ and I with similar morphology to A precipitated out in image 5. Simultaneously, precipitation of the small crystals 1 and 2 was also observed. With further drying (image 6), crystals of $\mathrm{E}, \mathrm{L}$ and $\mathrm{M}$ with similar morphology to A together with crystals $\mathrm{J}$ and $\mathrm{K}$ precipitated out. From 58 s, crystals 3, 4 began to grow and more crystals precipitated out gradually with a similar morphology to 3,4 , including 5 . However, only crystals 3 and 4 grew into big crystals with further evaporation of water (58-61 s, images 7-9). With continued drying, crystal 6 with similar morphology to 2 and 3 precipitated out abruptly. Simultaneously, solute precipitated out around the branches of crystal 5. At $72 \mathrm{~s}$, more crystals in circle $\mathrm{O}$ precipitated out surrounding crystal $\mathrm{D}$. At the end of the efflorescence process (images 11 and 12), all of the solute had precipitated out, although it is possible that residual water may remain within the solute particles. ${ }^{9,16,23,24}$

It can be concluded from the observation on the quartz substrate that the nucleation and crystallization of solutes in seawater supported on a hydrophilic substrate occur at the liquid-solid interface and the gas-liquid-solid three phase boundary. By contrast, observations of the efflorescence process on a PTFE substrate (in section 3.1) indicates that nucleation and crystallization of solutes in seawater occur mainly at the gas-liquid surface and in the liquid phase. Thus crystallization of seawater droplet on a hydrophilic substrate is mainly induced by heterogeneous nucleation, which is different from that on the hydrophobic substrate.

\subsection{Raman spectra of precipitates from a seawater droplet on quartz substrate}




\subsubsection{Precipitation of sulfate salts}

In contrast to the observations of droplet efflorescence on a hydrophobic substrate, most of the solid crystallites formed in an efflorescing sample on a quartz substrate remained in fixed positions once they were produced. These can then be located and probed by Raman microscopy. With the high spatial resolution of micro-Raman spectroscopy, the Raman spectra of the solid particles from D to M and A (in Fig.3) were collected as shown in Fig.4 and Fig.5. The Raman spectra of crystals A, D, E, F, G, H, I, J, K, L, and M showed a similar characteristic signature, a very strong band at $1012 \mathrm{~cm}^{-1}$, which can be assigned to $v_{1}\left(\mathrm{SO}_{4}^{2-}\right)^{25,26}$ as shown in Fig.4 and Fig.5. Hence, these eleven crystals contained a dominant sulfate mass fraction. This result is in accordance with the formation of sulfates during the early stages of the efflorescence process observed by Cheng et al. ${ }^{10,11}$

Previously, ${ }^{16}$ the bands around 1012 and $1151 \mathrm{~cm}^{-1}$ were assigned to $v_{1}\left(\mathrm{SO}_{4}^{2-}\right)$ and $v_{3}\left(\mathrm{SO}_{4}^{2-}\right)$, the bands at 432 and $476 \mathrm{~cm}^{-1}$ to $v_{2}\left(\mathrm{SO}_{4}^{2-}\right)$, and the bands around 602,635 , and $661 \mathrm{~cm}^{-1}$ to $v_{4}\left(\mathrm{SO}_{4}^{2-}\right)$ of $\mathrm{CaSO}_{4} \cdot 0.5 \mathrm{H}_{2} \mathrm{O}$. However, the solubility and crystallization kinetics of gypsum $\left(\mathrm{CaSO}_{4} \cdot 2 \mathrm{H}_{2} \mathrm{O}\right)$ and bassanite $\left(\mathrm{CaSO}_{4} \cdot 0.5 \mathrm{H}_{2} \mathrm{O}\right)$ depend also on the concentration of $\mathrm{NaCl}$ and $\mathrm{KCl} .{ }^{17}$ In addition, the $\mathrm{Na}_{2} \mathrm{Ca}_{5}\left(\mathrm{SO}_{4}\right)_{6} \cdot 3 \mathrm{H}_{2} \mathrm{O}$ structure is quite similar to $\mathrm{CaSO}_{4} \cdot 0.5 \mathrm{H}_{2} \mathrm{O},{ }^{17,27}$ and has been observed to form in the crystallization of $\mathrm{CaSO}_{4}-\mathrm{Na}_{2} \mathrm{SO}_{4}-\mathrm{H}_{2} \mathrm{O}$ and $\mathrm{CaSO}_{4}-\mathrm{NaSO}_{4}-$ $\mathrm{NaCl}-\mathrm{H}_{2} \mathrm{O}$ solutions ${ }^{25-29}$ and salt lake solutions. ${ }^{30}$ The Raman spectral assignments of the sulfates observed in the present work and the reference data from the literature ${ }^{31-35}$ for $\mathrm{CaSO}_{4}$. $0.5 \mathrm{H}_{2} \mathrm{O}$ and $\mathrm{Na}_{2} \mathrm{Ca}_{5}\left(\mathrm{SO}_{4}\right)_{6} \cdot 3 \mathrm{H}_{2} \mathrm{O}^{30}$ are presented in Table 1 . We assign the sulfates of crystals L, D, A, E, and $\mathrm{M}$ (Fig.4) to $\mathrm{Na}_{2} \mathrm{Ca}_{5}\left(\mathrm{SO}_{4}\right)_{6} \cdot 3 \mathrm{H}_{2} \mathrm{O}$ based on the high similarity of the $v_{1}\left(\mathrm{SO}_{4}^{2-}\right)$ to $v_{4}\left(\mathrm{SO}_{4}^{2-}\right)$ vibrational band frequencies. $\mathrm{CaSO}_{4} \cdot x \mathrm{H}_{2} \mathrm{O}(0.5 \leq x \leq$ $0.8)$ is formed with different degrees of hydration depending on the $\mathrm{RH}^{36-39} \mathrm{Na}_{2 x} \mathrm{Ca}_{6-x}\left(\mathrm{SO}_{4}\right)_{6} \cdot 3 \mathrm{H}_{2} \mathrm{O}(0<x<1)$ has been observed to form during efflorescence of the $\mathrm{CaSO}_{4}-\mathrm{NaSO}_{4}-\mathrm{NaCl}-\mathrm{H}_{2} \mathrm{O}$ system. ${ }^{28}$ We suggest that the different intensity ratios seen between 432 and $476 \mathrm{~cm}^{-1}$ Raman bands for the two groups of
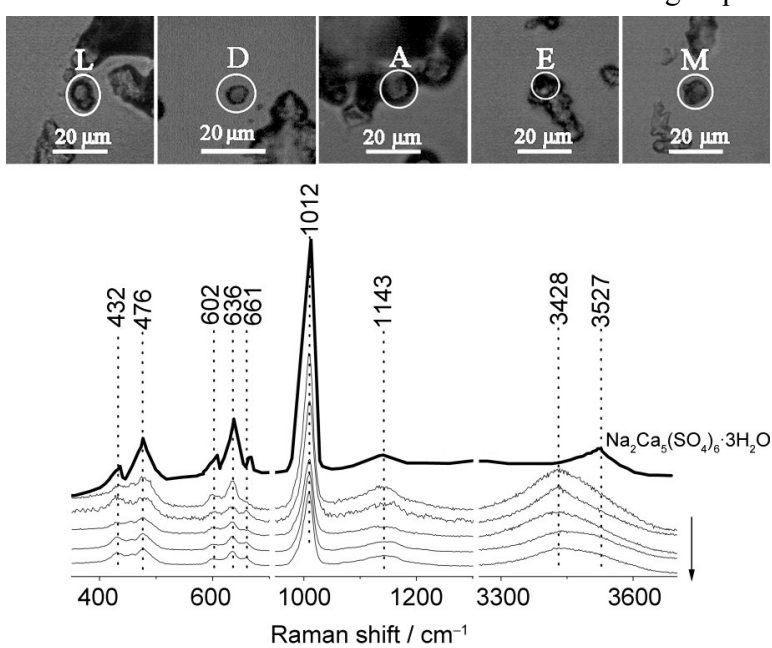

Fig.4 Raman spectra of $\mathrm{Na}_{2} \mathrm{Ca}_{5}\left(\mathrm{SO}_{4}\right)_{6} \cdot 3 \mathrm{H}_{2} \mathrm{O}$ and crystals $\mathrm{L}$, D, A, E, M (from top to bottom)

The spectrum of $\mathrm{Na}_{2} \mathrm{Ca}_{5}\left(\mathrm{SO}_{4}\right)_{6} \cdot 3 \mathrm{H}_{2} \mathrm{O}$ is observed by Mees et al. ${ }^{30}$.
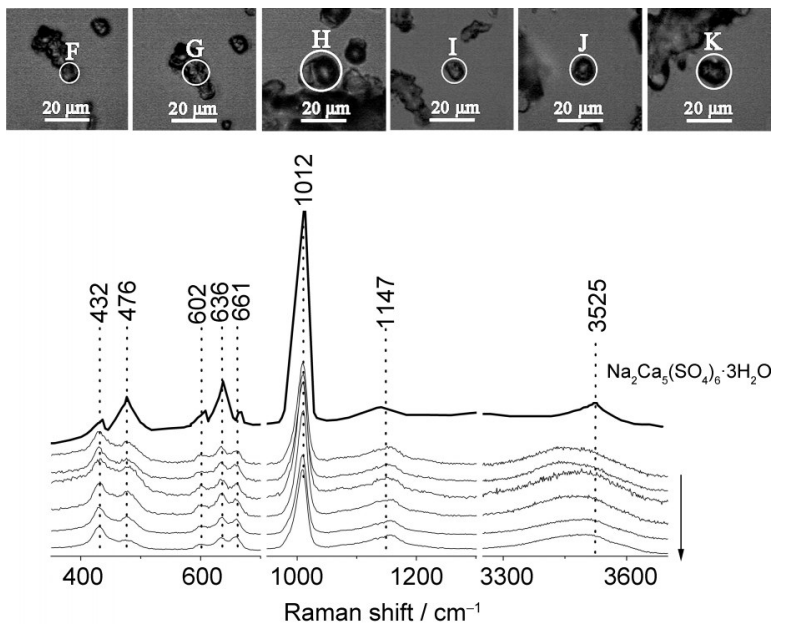

Fig.5 Raman spectra of $\mathrm{Na}_{2} \mathrm{Ca}_{5}\left(\mathrm{SO}_{4}\right)_{6} \cdot 3 \mathrm{H}_{2} \mathrm{O}$ and crystals $\mathrm{F}, \mathrm{G}, \mathrm{H}$, I, J, $\mathrm{K}$ (from top to bottom)

The spectrum of $\mathrm{Na}_{2} \mathrm{Ca}_{5}\left(\mathrm{SO}_{4}\right)_{6} \cdot 3 \mathrm{H}_{2} \mathrm{O}$ is observed by Mees et al. ${ }^{30}$

spectra A, D, E, L, M and F, G, H, I, J, K can be attributed to the different molar ratio of $\mathrm{Na}^{+} / \mathrm{Ca}^{2+}$ in the two possible double salts. We assign the crystals of $F, G, H, I, J$, and $K$ to $\mathrm{Na}_{2 x} \mathrm{Ca}_{6-x}\left(\mathrm{SO}_{4}\right)_{6} \cdot 3 \mathrm{H}_{2} \mathrm{O}(0<x<1)$ and propose that the $v(\mathrm{OH})$ around $3428 \mathrm{~cm}^{-1}$ in the spectra of crystals A, D, E, L, and M possibly correlates to the residual water associated with the crystals of F, G, H, I, J, and K.

It was observed from Fig. 3 that the crystals A, D, E, L, and M moved to some extent during the water evaporation process. However, the crystals of F, G, H, I, J, and K were located at the same positions throughout the whole efflorescence process. We conclude that these data suggest that the crystallization of $\mathrm{Na}_{2} \mathrm{Ca}_{5}\left(\mathrm{SO}_{4}\right)_{6} \cdot 3 \mathrm{H}_{2} \mathrm{O}$ (A, D, E, L, and M) occurs at the surface of the droplet, while the crystallization of $\mathrm{Na}_{2 x} \mathrm{Ca}_{6-x}\left(\mathrm{SO}_{4}\right)_{6} \cdot 3 \mathrm{H}_{2} \mathrm{O}$ $(0<x<1 ; \mathrm{F}, \mathrm{G}, \mathrm{H}, \mathrm{I}, \mathrm{J}$, and $\mathrm{K})$ occurs at the liquid-substrate interface. We therefore propose that the formation of $\mathrm{Na}_{2} \mathrm{Ca}_{5}\left(\mathrm{SO}_{4}\right)_{6}$. $3 \mathrm{H}_{2} \mathrm{O}$ and $\mathrm{Na}_{2 x} \mathrm{Ca}_{6-x}\left(\mathrm{SO}_{4}\right)_{6} \cdot 3 \mathrm{H}_{2} \mathrm{O}(0<x<1)$ could be arise from homogenous and heterogeneous nucleation, respectively.

\subsubsection{Comparison of the crystallization and growth of $\mathrm{Na}_{2} \mathrm{Ca}_{5}\left(\mathrm{SO}_{4}\right)_{6} \cdot 3 \mathrm{H}_{2} \mathrm{O}$ and $\mathrm{CaSO}_{4} \cdot 2 \mathrm{H}_{2} \mathrm{O}$ during different $\mathrm{RH}$ changing process}

Table 1 Raman spectra of $\mathrm{CaSO}_{4} \cdot 0.5 \mathrm{H}_{2} \mathrm{O}$ (bassanite) and $\mathrm{Na}_{2} \mathrm{Ca}_{5}\left(\mathrm{SO}_{4}\right)_{6} \cdot \mathbf{3} \mathrm{H}_{2} \mathrm{O}$

\begin{tabular}{crrrrrrr}
\hline \multirow{2}{*}{ Assignment } & \multicolumn{7}{c}{ Raman shift $/ \mathrm{cm}^{-1}$} \\
\cline { 2 - 8 }$v_{2}\left(\mathrm{SO}_{4}^{2-}\right)$ & 438 & 428 & 434 & 421 & 427 & 436 & 432 \\
& 494 & 488 & 488 & 490 & 489 & 476 & 476 \\
$v_{4}\left(\mathrm{SO}_{4}^{2-}\right)$ & 602 & & & & & 608 & 602 \\
& 636 & 629 & 630 & 630 & 628 & 637 & 636 \\
$v_{1}\left(\mathrm{SO}_{4}^{2-}\right)$ & 676 & 667 & 672 & 680 & 668 & 665 & 661 \\
$v_{3}\left(\mathrm{SO}_{4}^{2-}\right)$ & 1018 & 1015 & 1017 & 1014 & 1015 & 1013 & 1012 \\
& 1132 & 1131 & 1124 & & 1128 & & \\
& 1150 & 1150 & 1154 & 1152 & & 1143 & 1143 \\
& 1174 & 1166 & 1168 & 1174 & & & \\
$v\left(\mathrm{H}_{2} \mathrm{O}\right)$ & & 3560 & 3516 & 3554 & 3550 & 3527 & 3525 \\
& & 3630 & 3568 & 3616 & & & \\
Reference & 28 & 29 & 30 & 31 & 32 & 27 & present work \\
\hline
\end{tabular}


In order to evaluate the influence of the rate of RH change on the crystallization of the sulfates, different desiccation speeds were investigated. The images of precipitated salt crystals observed under slow (a) and quick (b) desiccation process with different morphologies are shown in Fig.6(a, b). The trends in the measured RH with time are shown in Fig.7 and the Raman spectra of the two residual sea salt particles are shown in Fig.8. Fig.7 (process 1) and Fig.6(a) indicate that a particle composed of two distinct halves $(\mathrm{P})$ precipitated out at $74 \% \mathrm{RH}$ and grew to $10 \mu \mathrm{m}$ (diameter) in $0.5 \mathrm{~min}$ during the slower desiccation process. Fig.7 (process 2) and Fig.6(b) indicate that a rod-like sea salt (Q) precipitated out at $82 \% \mathrm{RH}$ and grew to $15 \mu \mathrm{m}$ (long) in 0.5 min during the quicker desiccation process.

By comparing with the Raman spectra of gypsum observed by Chemtob et $a l^{40}$ and with crystal $\mathrm{D}$ observed in Fig.3, the crystals $\mathrm{P}$ and $\mathrm{Q}$ were assigned to be $\mathrm{Na}_{2} \mathrm{Ca}_{5}\left(\mathrm{SO}_{4}\right)_{6} \cdot 3 \mathrm{H}_{2} \mathrm{O}$ and $\mathrm{CaSO}_{4} \cdot 2 \mathrm{H}_{2} \mathrm{O}$ respectively.

In order to illustrate the difference of crystal growth speed for $\mathrm{Na}_{2} \mathrm{Ca}_{5}\left(\mathrm{SO}_{4}\right)_{6} \cdot 3 \mathrm{H}_{2} \mathrm{O}$ and $\mathrm{CaSO}_{4} \cdot 2 \mathrm{H}_{2} \mathrm{O}$, we calculated these two kinds of crystal volumes during different time with the ImageJ software. ${ }^{41}$ The area of the crystal can be obtained directly by selecting the image contour with the ImageJ software. The height of the crystal can be calculated according to the contrast in brightness, ${ }^{42}$ also obtained with the ImageJ software. This then allows the volume of the crystal to be calculated by the area data multiplied by the height.

The time-dependencies of the volumes of the $\mathrm{Na}_{2} \mathrm{Ca}_{5}\left(\mathrm{SO}_{4}\right)_{6}$. $3 \mathrm{H}_{2} \mathrm{O}$ and $\mathrm{CaSO}_{4} \cdot 2 \mathrm{H}_{2} \mathrm{O}$ particles are showed in Fig.9. A linear fit to the experimental data of the volume of crystal versus time shows good linear relationship. Linear fitting equations are $V=1.80 t$, corresponding to the volume of $\mathrm{Na}_{2} \mathrm{Ca}_{5}\left(\mathrm{SO}_{4}\right)_{6}$. $3 \mathrm{H}_{2} \mathrm{O}$ versus time at $74 \% \mathrm{RH} ; V=0.68 t$, corresponding to the volume of $\mathrm{CaSO}_{4} \cdot 2 \mathrm{H}_{2} \mathrm{O}$ versus time at $82 \% \mathrm{RH}$. Five further sets of experimental data of the volume of the crystal versus time are shown by the shaded regions in Fig.9. $\mathrm{Na}_{2} \mathrm{Ca}_{5}\left(\mathrm{SO}_{4}\right)_{6}$. $3 \mathrm{H}_{2} \mathrm{O}$ precipitated out at a lower $\mathrm{RH}$ with a faster crystal growth speed during the quicker desiccation process. (a)
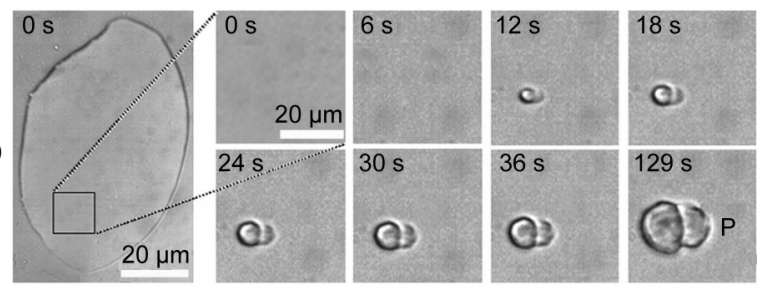

(b)

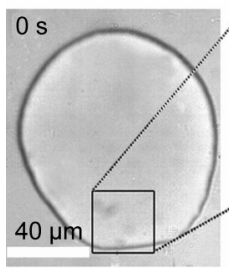

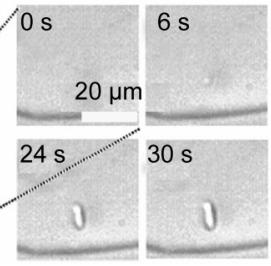

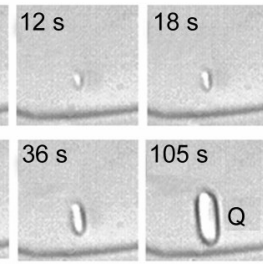

Fig.6 (a) Images of the growing $\mathrm{Na}_{2} \mathrm{Ca}_{5}\left(\mathrm{SO}_{4}\right)_{6} \cdot 3 \mathrm{H}_{2} \mathrm{O}$ (P) during the $\mathrm{RH}$ shrinking process, (b) images of the growing $\mathrm{CaSO}_{4}$. $2 \mathrm{H}_{2} \mathrm{O}(\mathrm{Q})$ during the slow $\mathrm{RH}$ decreasing process

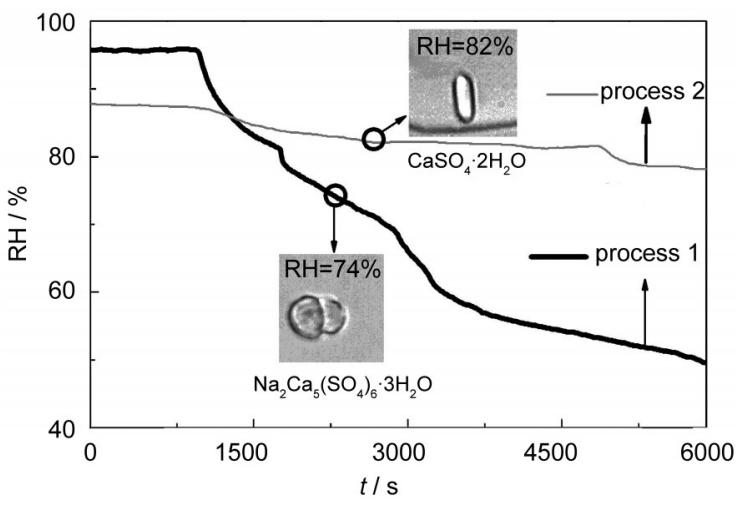

Fig.7 Relative humidity evolution curves of two different processes

The back line indicates the quick RH decreasing process (process 1), during which $\mathrm{Na}_{2} \mathrm{Ca}_{5}\left(\mathrm{SO}_{4}\right)_{6} \cdot 3 \mathrm{H}_{2} \mathrm{O}$ was observed at $\sim 74 \% \mathrm{RH}$. The gray line indicates the slow $\mathrm{RH}$ changing process (process 2), during which the $\mathrm{CaSO}_{4} \cdot 2 \mathrm{H}_{2} \mathrm{O}$ was observed.

\subsubsection{Precipitation of sodium chloride}

With similar morphology to a pure $\mathrm{NaCl}$ crystal (Fig.1(f)) and a lack of any signature Raman features, crystals 1 to 6 can be assigned to be composed of mainly $\mathrm{NaCl}$. It can be observed from Fig. 3 that the $\mathrm{NaCl}$ crystals from 1 to 4 grew into large crystals. However, crystal 5 remained at the same location and with the same size. Crystal 6 occurred more immediately than crystals 1 to 4 and grew into a cubic structure. A reason for this difference may be that crystals 1 to 4 are located at the edge of the droplet, which is closer to the dry $\mathrm{N}_{2}$ gas, where the water activity is expected to be much lower. Thus, the concentration of aqueous $\mathrm{Na}^{+}$and $\mathrm{Cl}^{-}$around the crystals 1 to 4 be-
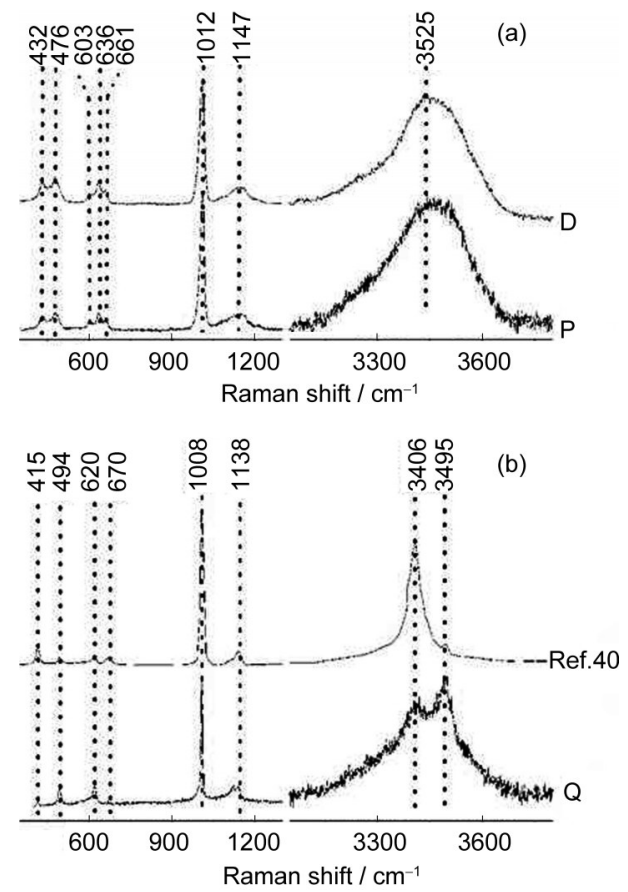

Fig.8 (a) Raman spectra of crystals $P$ shown in Fig.6(a) and $D$ in Fig.4, (b) Raman spectra of crystals $Q$ in Fig.6(b) and the $\mathrm{CaSO}_{4} \cdot 2 \mathrm{H}_{2} \mathrm{O}$ observed by Chemtob et al. ${ }^{40}$ 


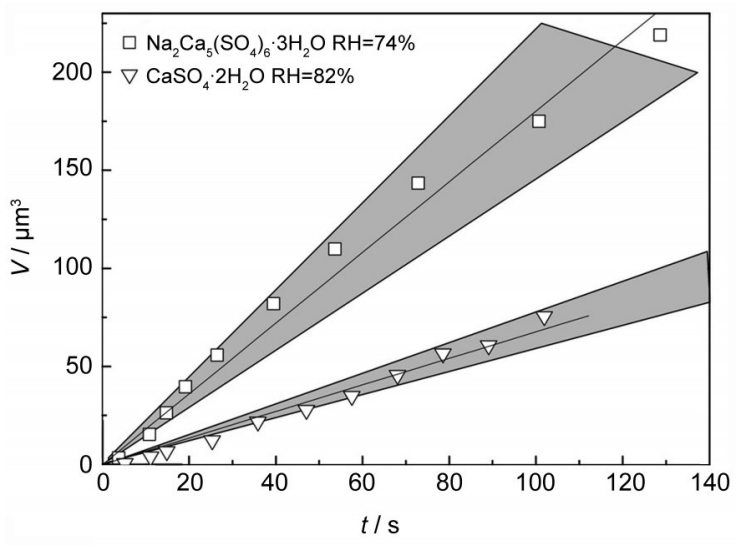

Fig.9 Volume changing rate of $\mathrm{Na}_{2} \mathrm{Ca}_{5}\left(\mathrm{SO}_{4}\right)_{6} \cdot 3 \mathrm{H}_{2} \mathrm{O}$ and $\mathrm{CaSO}_{4} \cdot$ $2 \mathrm{H}_{2} \mathrm{O}$ versus time

comes supersaturated earlier than in the bulk of the seawater droplet. The concentration of $\mathrm{Na}^{+}$and $\mathrm{Cl}^{-}$surrounding the crystal branch of $\mathrm{NaCl}$ would be expected to initially decrease, commensurate with the formation and growth of the initial $\mathrm{NaCl}$ crystal. It would then be expected that diffusion in the liquid phase from regions of higher concentration would follow allowing the crystal branch to grow bigger. This would provide a reason for why the morphology of crystals 1 to 4 is not perfectly cubic.

Judging from the observation that crystal 5 did not move during the droplet evaporation process, we inferred that crystal 5 was formed on the substrate rather than in the liquid phase. Since crystal 5 was located at the center and bottom of the droplet, the concentration of the solution would not be expected to reach the same level of supersaturation as the concentration at the droplet surface. In this case, crystal 5 would be expected to retain the same morphology and size until the end of the efflorescence process. The formation of crystals 1 to 5 is attributable to heterogeneous crystallization. However, crystal 6 grew into cubic structure abruptly (image 10). The precipitation of crystal 6 with cube morphology is quite different from that of crystals 1 to 5 . Such a difference is likely to result from the growth of crystal 6 in the liquid phase rather than on the substrate and, thus, might be induced by homogeneous crystallization. It can be concluded from the above analysis that the growth of $\mathrm{NaCl}$ in the liquid phase is mainly based on homogeneous nucleation, and the morphology of the crystallized $\mathrm{NaCl}$ is normally cubic. However, if an interface exists, crystallization of $\mathrm{NaCl}$ occurs through heterogeneous nucleation and the $\mathrm{NaCl}$ crystal can be expected to normally feature with asymmetric branch structures.

\subsubsection{Precipitation of $\mathrm{KMgCl}_{3} \cdot 6 \mathrm{H}_{2} \mathrm{O}$}

At $72 \mathrm{~s}$, crystal $\mathrm{O}$ was observed at the edge of the droplet (image 11 in Fig.3). Raman spectra of crystal $\mathrm{O}$ are shown in Fig.10(a). The $\mathrm{OH}$ stretching band of crystal $\mathrm{O}$ is located at $\sim 3430 \mathrm{~cm}^{-1}$ with an obvious shoulder at $3250 \mathrm{~cm}^{-1}$. Spectra of pure $\mathrm{KMgCl}_{3} \cdot 6 \mathrm{H}_{2} \mathrm{O}$ observed in our previous static experiment ${ }^{16}$ are presented in Fig.10(a) for comparison. It can be ob-

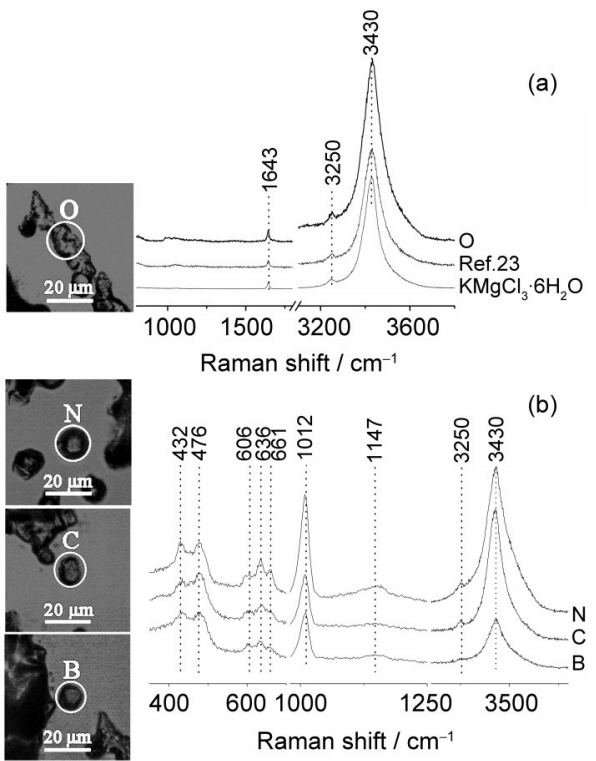

Fig.10 Raman spectra of crystals $O$ in Fig.3, from Ref.23, and pure $\mathrm{KMgCl}_{3} \cdot 6 \mathrm{H}_{2} \mathrm{O}$ (a); Raman spectra of crystals $\mathrm{N}, \mathrm{C}$, and $\mathrm{B}$ in Fig.3, corresponding to precipitated $\mathrm{Na}_{2 x} \mathrm{Ca}_{6-x}\left(\mathrm{SO}_{4}\right)_{6} \cdot 3 \mathrm{H}_{2} \mathrm{O}(0<x<1)$ covered by $\mathrm{KMgCl}_{3} \cdot 6 \mathrm{H}_{2} \mathrm{O}$ (b)

served that the three spectra presented in Fig.10(a) are in good accordance, and crystal $\mathrm{O}$ can be assigned to the $\mathrm{KMgCl}_{3}$. $6 \mathrm{H}_{2} \mathrm{O}$ hydrated salt.

Crystals B, C, and N were observed (image 3 in Fig.3) at the edge of the droplet and their Raman spectra are shown in Fig.10(b). The primary difference between the Raman spectra for crystals $\mathrm{B}, \mathrm{C}$ and $\mathrm{N}$ and that from crystal $\mathrm{O}$ is the appearance of the vibration of $\mathrm{SO}_{4}^{2-}$. By comparing the frequencies and relative intensities of the bands in Fig.10(b) with that in Fig.4, we assigned the vibrational bands of $\mathrm{SO}_{4}^{2-}$ which appeared in the spectra of crystals $\mathrm{B}, \mathrm{C}$ and $\mathrm{N}$ to $\mathrm{Na}_{2} \mathrm{Ca}_{5}\left(\mathrm{SO}_{4}\right)_{6} \cdot 3 \mathrm{H}_{2} \mathrm{O}$. Considering the $\mathrm{Na}_{2} \mathrm{Ca}_{5}\left(\mathrm{SO}_{4}\right)_{6} \cdot 3 \mathrm{H}_{2} \mathrm{O}$ precipitated out of the seawater earlier on droplet surface, it can be inferred that the $\mathrm{KMgCl}_{3}$. $6 \mathrm{H}_{2} \mathrm{O}$ forms a coating on precipitated $\mathrm{Na}_{2} \mathrm{Ca}_{5}\left(\mathrm{SO}_{4}\right)_{6} \cdot 3 \mathrm{H}_{2} \mathrm{O}$.

\section{Conclusions}

In this work, an investigation of rapid efflorescence of single seawater droplets on hydrophobic PTFE and hydrophilic quartz substrates by micro-Raman spectroscopy combined with a high-speed camera is reported. For the droplet on the PTFE substrate, the formation of cubic $\mathrm{NaCl}$ crystals can be unambiguously identified. Although the crystallization of other components is expected, no unambiguous identification can be made. A hollow structured particle was obtained at the completion of the efflorescence process. For the droplet on the quartz substrate, the locations of crystals formed from different sea salt components during the efflorescence process and the composition of crystals at the end of the efflorescence were identified by the high-speed camera and Raman spectroscopy, respectively. 
We observed the existence of $\mathrm{Na}_{2} \mathrm{Ca}_{5}\left(\mathrm{SO}_{4}\right)_{6} \cdot 3 \mathrm{H}_{2} \mathrm{O}$ and $\mathrm{Na}_{2 x} \mathrm{Ca}_{6-x}\left(\mathrm{SO}_{4}\right)_{6} \cdot 3 \mathrm{H}_{2} \mathrm{O}(0<x<1)$ after the rapid efflorescence process and $\mathrm{CaSO}_{4} \cdot 2 \mathrm{H}_{2} \mathrm{O}$ after slow efflorescence process of sea water droplets. By comparing the morphology, locations and Raman spectra of different sea salts during and after the efflorescence process, we conclude that the nucleation and crystallization of sea salt components in a seawater droplet on the hydrophilic substrate mainly occurs at the liquid-substrate interface and the gas-liquid-solid three-phase boundaries. When crystallization is examined on the hydrophobic substrate, crystallization mainly occurs at the droplet surface and in the liquid phase. Thus, the crystallization of a seawater droplet on a hydrophobic substrate is induced by homogeneous nucleation consistent with the high contact angle. On a hydrophilic substrate, heterogeneous nucleation at either the liquid-substrate interface or the three-phase boundaries dominates the crystallization process.

\section{References}

(1) Fitzgerald, J. W. Atmos. Environ. 1991, 25A, 533.

(2) O'Dowd, C. D.; De Leeuw, G. Phil. Trans. Roy. Soc. A 2007, $365,1753$.

(3) O'Dowd, C. D.; Smith, M. H.; Consterdine, I. E.; Lowe, J. A. Atmos. Environ. 1997, 31, 73.

(4) Murphy, D. M.; Anderson, J. R.; Quinn, P. K.; McInnes, L. M.; Brechtel, F. J.; Kreidenweis, S. M.; Middlebrook, A. M.; Pósfai, M.; Thomson, D. S.; Buseck, P. R. Nature 1998, 392, 62.

(5) Latham, J.; Smith, M. H. Nature 1990, 347, 372.

(6) Laskin, A.; Gasper, D. J.; Wang, W.; Hunt, S. W.; Cowin, J. P.; Colson, S. D.; Finlayson-Pitts, B. J. Science 2003, 301, 340.

(7) De Haan, D. O.; Brauers, T.; Oum, K.; Stutz, J.; Nordmeyer, T.; Finlayson-Pitts, B. J. Int. Rev. Phys. Chem. 1999, 18, 343.

(8) Lewis, E. R.; Schwartz, S. E. Sea Salt Aerosol Production: Mechanisms, Methods, Measurements, and Models; American Geophysical Union: Washington, D. C., 2004; pp 1-36.

(9) Tang, I. N.; Tridico, A. C.; Fung, K. H. J. Geophys. Res. 1997, $102,23269$.

(10) Cheng, R. J.; Blanchard, D. C.; Cipriano, R. J. Atmos. Res. 1988, 22, 15.

(11) Cheng, R. J. Atmos. Aer. Nuc. 1988, 309, 589.

(12) Harvie, C. E.; Weare, J. H.; Hardie, L. W.; Eugster, H. P. Science 1980, 208, 498.

(13) Psófai, M.; Buseck, P. R. Annu. Rev. Earth Planet. Sci. 2010, 38 , 17.

(14) Ma, Y. T.; Xia, S. P.; Gao, S. Y. Acta Phys. -Chim. Sin. 2001, 17 (11), 1021. [马玉涛, 夏树屏, 高世扬. 物理化学学报, 2001, 17 (11), 1021.]

(15) Wang, F.; Zhao, L. J.; Zhang, Y. H. Chin. Sci. Bull. 2008, 53 (14), 2139. [王 枫, 赵利军, 张暳宏. 科学通报, 2008, 53 (14), 2139.]

(16) Xiao, H. S.; Dong, J. L.; Wang, L. Y.; Zhao, L. J.; Wang, F.;
Zhang, Y. H. Environ. Sci. Technol. 2008, 42, 8698.

(17) Freyer, D.; Voigt, W. Mon. Chem. 2003, 134, 693.

(18) Voigt, W. Pure Appl. Chem. 2001, 73, 831.

(19) Yeung, M. C.; Chan, C. K. Aerosol Sci. Technol. 2010, 44, 269.

(20) Liu, Y. J.; Zhu, T.; Zhao, D. F.; Zhang, Z. F. Atmos. Chem. Phys. 2008, 8, 7205.

(21) Hiratsuka, K.; Bohno, A.; Endo, H. J. Phys.: Conf. Ser. 2007, $89,012012$.

(22) Braun, C.; Krieger, U. K. Opt. Express 2001, 8, 314.

(23) Cziczo, D. J.; Nowak, J. B.; Hu, J. H.; Abbatt, J. P. D. J. Geophys. Res. 1997, 102, 18843.

(24) Zhao, L. J.; Zhang, Y. H.; Wei, Z. F.; Cheng, H.; Li, X. H. J. Phys. Chem. A 2006, 110, 951.

(25) Ross, S. D. Inorganic Infrared and Raman Spectra. McGrawHill: London, 1972; p 140.

(26) Reisdorf, K.; Abriel, W. Neues Jahrb. Mineral.-Abh. 1987, 157, 35.

(27) Freyer, D.; Fischer, S.; Köhnke, K.; Voigt, W. Solid State Ionics 1997, 96, 29.

(28) Freyer, D.; Reck, G.; Bremer, M.; Voigt, W. Mon. Chem. 1999, 130, 1179.

(29) Hill, A. F.; Wills, J. H. J. Am. Chem. Soc. 1938, 60, 1647.

(30) Mees, F.; Hatert, F.; Rowe, R. Mineral. Mag. 2008, 72, 1307.

(31) Bensted, J. J. Am. Ceram. Soc. 1976, 59, 140.

(32) Kosztolanyi, C.; Mullis, J.; Weidmann, M. Chem. Geol. 1987, $61,19$.

(33) Chang, H.; Huang, P. J.; Hou, S. C. Mater. Chem. Phys. 1999, $58,12$.

(34) Prasad, P. S. R.; Pradhan A.; Gowd, T. N. Curr. Sci. 2001, 80, 1203.

(35) Liu, Y. M.; Wang, A.; Freeman, J. J. Raman, MIR, and NIR Spectroscopic Study of Calcium sulfates: Gypsum, Bassanite, and Anhydrite. In Lunar and Planetary Science XL, 40th Lunar and Planetary Science Conference, Woodlands, Texas, March 23-27, 2009.

(36) Oetzel, M.; Heger, G.; Koslowski, T. ZKG Int. 2000, 53, 354.

(37) Kuzel, H. J.; Hauner, M. Zement-kalk-gips 1987, 40, 628.

(38) Bushuev, N. N. Zh. Neorg. Khim. 1982, 27, 610.

(39) Abriel, W.; Nesper, R. Z. Kristall. 1993, 205, 99.

(40) Chemtob, S. M.; Arvidson, R. E.; Fernández-Remolar, D. C. et al. Identification of Hydrated Sulfates Collected in the Northern Rio Tinto Valley by Reflectance and Raman Spectroscopy. In Lunar and Planetary Science XXXVII, 37th Lunar and Planetary Science Conference, League City, Texas, March 13-17, 2006.

(41) Abramoff, M. D.; Magelhaes, P. J.; Ram, S. J. Biophotonics Int. 2004, 11 (7), 36.

(42) Van Driessche, A. E. S.; Garcia-Ruiz, J. M.; Delgado-Lopez, J. M.; Sazaki, G. Cryst. Growth Des. 2010, 10 (9), 3909. 